\title{
PERAN AKUNTAN DALAM PEMBERANTASAN KORUPSI
}

\author{
Haryono Umar \\ Komisi Pemberantasan Korupsi Republik Indonesia \\ Jl. Ir. H. Juanda No. 36, Jakarta Pusat 10110
}

\begin{abstract}
ABSTRAK. Peran akuntan sangat penting dalam memastikan laporan pertanggungjawaban keuangan dan kinerja yang tepat dengan menerapkan fungsi kontrol. Akuntansi adalah proses mengkomunikasikan informasi keuangan mengenai suatu badan usaha kepada pengguna seperti pemegang saham dan manajer. Komunikasi umumnya dalam bentuk laporan keuangan yang menunjukkan dalam bentuk uang sumber daya ekonomi di bawah kendali manajemen; seni terletak dalam memilih informasi yang relevan kepada pengguna dan dapat diandalkan. Akuntansi adalah proses pencatatan, klasifikasi, dan meringkas secara signifikan dan dalam bentuk uang, transaksi dan peristiwa yang, setidaknya untuk sebagian, karakter keuangan, dan menafsirkan hasil daripadanya. Informasi yang diberikan oleh akuntan dapat bertukar proses pengambilan keputusan. Informasi ini diperlukan untuk menerapkan sistem pemerintahan di suatu organisasi. Penerapan sistem pemerintahan adalah praktik yang baik untuk mencegah korupsi. Pemerintahan adalah sistem nilai, kebijakan dan institusi dimana masyarakat mengelola urusan ekonomi, politik dan sosial melalui interaksi di dalam dan di antara masyarakat, negara sipil dan sektor swasta. Ini adalah cara masyarakat mengorganisasi dirinya sendiri untuk membuat dan melaksanakan keputusan-mencapai kesepakatan pengertian, saling dan tindakan. Ini terdiri dari mekanisme dan proses bagi warga dan kelompok untuk mengartikulasikan kepentingan mereka, menengahi perbedaan mereka dan melaksanakan hak hukum dan kewajiban mereka. Ini adalah aturan, lembaga dan praktek-praktek yang menetapkan batas-batas dan memberikan insentif bagi individu, organisasi dan perusahaan. Pemerintahan, termasuk dimensi sosial, politik dan ekonomi, beroperasi pada setiap tingkat perusahaan manusia, baik itu rumah tangga, desa, kota, negara, kawasan, atau dunia ". Audit memberikan kontribusi dalam strategi memerangi korupsi. kerugian Negara dapat ditemukan oleh penerapan audit yang efektif seperti audit forensik, audit investigatif atau audit jenis lainnya. Korupsi adalah "penyalahgunaan jabatan publik untuk keuntungan pribadi." Karena itu, ia melibatkan perilaku yang tidak tepat dan tidak sah pejabat publik-pelayanan, baik politisi dan pegawai negeri sipil, yang posisinya menciptakan peluang bagi pengalihan uang dan aset dari pemerintah untuk diri mereka sendiri dan mereka kaki. Salah satu contoh korupsi adalah penipuan. pelaporan keuangan sebagai melakukan kecurangan disengaja atau ceroboh, baik perbuatan atau kelalaian, yang menghasilkan laporan keuangan material yang menyesatkan. Auditor harus mencari tahu dan laporan ini kegiatan kriminal seperti yang diceritakan oleh standar auditing. Makalah ini menganalisa peran akuntan dalam memberantas korupsi.
\end{abstract}

Kata Kunci: Akuntan, Korupsi, Pemerintahan 


\section{ACCOUNTANTS 'ROLE IN COMBATING CORRUPTION}

ABSTRACT. The role of accountant is vital in ensuring the proper financial and performance accountability report by implementing control function. Accountancy is the process of communicating financial information about a business entity to users such as shareholders and managers. The communication is generally in the form of financial statements that show in money terms the economic resources under the control of management; the art lies in selecting the information that is relevant to the user and is reliable. Accounting is a process of recording, classifying, and summarizing in a significant manner and in terms of money, transactions and events which are, in part at least, of financial character, and interpreting the results thereof. The information provided by accountant could exchange the decision making process. The information is needed for implementing governance system in an organization. Implementing governance system is a good practice for preventing corruption. Governance is the system of values, policies and institutions by which a society manages its economic, political and social affairs through interactions within and among the state, civil society and private sector. It is the way a society organizes itself to make and implement decisions -achieving mutual understanding, agreement and action. It comprises the mechanisms and processes for citizens and groups to articulate their interest, mediate their differences and exercise their legal rights and obligations. It is the rules, institutions and practices that set limits and provide incentives for individuals, organizations and firms. Governance, including its social, political and economic dimensions, operates at every level of human enterprise, be it the household, village, municipality, nation, region or globe". Audit contributes in corruption combat strategy. State losses could be found out by implementing an effective audit such as forensic audit, investigative audit or other types of auditing. Corruption is "the misuse of public office for private gain." As such, it involves the improper and unlawful behavior of public-service officials, both politicians and civil servants, whose positions create opportunities for the diversion of money and assets from government to themselves and their accomplices. One of corruption example is fraud. fraudulent financial reporting as intentional or reckless conduct, whether act or omission, that results in materially misleading financial statements. Auditor should find out and report this criminal activities as told by the auditing standards. This paper analyzes the accountant's role in combating corruption.

Key words: accountant, corruption, governance

\section{PENDAHULUAN}

Informasi akuntansi yang tergambar dalam laporan keuangan merupakan bentuk komunikasi perusahaan untuk berakuntabilitas kepada para stakeholdersnya. Akuntabilitas merupakan kewajiban untuk menjawab dan menerangkan kinerja dan tindakan organisasi kepada pihak-pihak yang memiliki hak untuk 
meminta jawaban dan keterangan dari pihak yang bertanggungjawab atau pihak yang berkewajiban lainnya. Informasi yang harus dijawab tersebut berkaitan dengan implementasi "amanah" yang diterima perusahaan dari pihak-pihak yang telah "mempercayakan/memberi mandat" untuk mengelola sumber daya perusahaan.

Sebagai pihak yang telah mendapatkan kepercayaan dari pemilik untuk mengelola sumber daya perusahaan, manajemen wajib mempertanggungjawabkan segala tindakannya dalam mengimplementasikan amanah tersebut. Pertanggungjawaban dapat dilakukan secara tertulis maupun lisan, secara periodik maupun insidential, umum maupun khusus. Dari perspektif akuntansi, pertanggungjawaban pengelolaan perusahaan dilakukan secara tertulis dan dilakukan secara periodik setahun sekali. Laporan keuangan merupakan wujud akuntabilitas kepada pemilik (Belkaoui, 1993).

Romney and Steinbart (2003) menyatakan: "Information, is data that have been processed and organized into output that is meaningful to the person who receives it. Informasi merupaan data yang telah tersusun sehingga dapat memberikan nilai tambah berupa pengetahuan kepada penggunanya. Informasi yang berkualitas dari manajemen adalah informasi yang dapat mengubah (alter) opini penggunanya dalam rangka pengambilan keputusan (Floridi, 2004).

Akuntabilitas digambarkan sebagai pemenuhan kewajiban manajemen untuk menyampaikan informasi (disclosure) berupa laporan keuangan kepada publik (investors dan creditors) (Barata et al, 1999 dan Carlin, 2001). Informasi yang kredibel untuk mendukung akuntabilitas manajemen harus memenuhi kriteria yang mencakup (Ikatan Akuntan Indonesia,2002): a. dapat difahami (Understandability); b.relevan (Relevance), c.kehandalan (Reliability); d.dapat diperbandingkan (Comparability).

Kandungan informasi keuangan yang disampaikan kepada publik menunjukkan kinerja yang telah dicapai perusahaan dalam mengimplementasikan amanah yang diterimanya. Kinerja merupakan kondisi yang harus diketahui dan diinformasikan kepada pihak-pihak tertentu untuk mengetahui tingkat pencapaian hasil suatu organisasi dihubungkan dengan misi yang diembannya, serta mengetahui dampak positif dan negatif dari suatu kebijakan operasional yang diambil. Dengan adanya informasi mengenai kinerja suatu entitas atau organisasi, maka akan dapat diambil tindakan yang diperlukan seperti koreksi atas kebijakan, meluruskan kegiatan-kegiatan utama, bahan untuk perencanaan, penentuan tingkat keberhasilan (persentase pencapaian misi), dan pembuatan keputusan.

Akuntabilitas muncul sebagai jawaban terhadap permasalahan asymmetrical information. Menurut teori ini, kelanggengan suatu organisasi ditentukan oleh kemampuan untuk menciptakan informasi yang terbuka, seimbang dan merata bagi semua pihak yang berkepentingan (stakeholders). Sementara itu, teori ini justru beranggapan bahwa yang banyak terjadi adalah adanya kesenjangan informasi (asymmetrical information) pada pihak-pihak yang terkait, terutama antara pihak manajemen yang mempunyai akses langsung dengan subyek yang diinformasikan dengan pihak konstituen yang tidak memiliki akses langsung pada objek yang diinformasikan tersebut. 


\section{PEMBERANTASAN KORUPSI}

Korupsi dapat dilihat dari pengertian yang sempit dan luas. Pavarala (1996) membagi dua kelompok pengertian korupsi yakni pengertian legal yang sempit dan pengertian yang juga memperhatikan moral dan etika. Dalam arti sempit, korupsi meliputi penyuapan (bribery), penggunaan barang publik tidak sesuai dengan peruntukannya (misappropriation of public resources), komisi (kickbacks commissions), penyelewengan (embezzlement), dan pemberian melebihi nilai yang diperkenankan (gifts beyond a certain value). Dalam arti luas, korupsi mencakup hal-hal di atas ditambah nepotisme/pavoritisme, ketidakjujuran (dishonesty), dan kejahatan intelektual (intellectual crime).

Dengan demikian korupsi adalah penyalahgunaan kekuasaan dan jabatan pada organisasi publik untuk keuntungan pribadi, penyalahgunaan jabatan yang dapat menghasilkan uang untuk kepentingan partai, suku, kelas, teman, keluarga yang sangat dirahasiakan terhadap pihak lain di luar kalangan sendiri itu (Tanzi, 1998 ; Alatas, 1987; Pope, 2000; dan Langseth ,1999).

Korupsi sama halnya dengan penyakit yang menyerang berbagai sektor seperti ekonomi, politik, kultur, etika, moral bahkan agama. Hal ini banyak dikenal sebagai korupsi, kolusi, dan nepotisme (KKN) atau sistem kroni. Kolusi merupakan persekongkolan, permufakatan, persetujan, atau kesepakatan yang tidak baik untuk melakukan hal-hal yang menimbulkan kerugian pada pihak tertentu. Nepotisme adalah tindakan atau keberpihakan yang dilakukan dengan landasan hubungan kekerabatan. Sedangkan sistem kroni merupakan kesepakatan bersama dalam pelaksanaan tugas-tugas untuk keuntungan pribadi dan kelompok.

Penelitian yang dilakukan oleh Center for the Study of Democracy, University of California Irvine (1998) dengan judul 'Accounting for Corruption: Economic Structure, Democratic Norms, and Trade'. Penelitian dilakukan pada 50 negara berhasil menjawab hipotesis yakni makin tinggi korupsi akan: a. meningkatnya kontrol pemerintah terhadap ekonomi, b. semakin menurunnya norma dan nilainilai, c. semakin mengecilnya integrasi negara tersebut dengan perekonomian dunia.

Hasil penelitian mereka tersebut memperlihatkan bahwa korupsi telah menurunkan kepercayaan banyak pihak bukan hanya dari dalam negeri namun juga luar negeri. Maraknya (rampant) korupsi menjadikan ekonomi biaya tinggi sehingga akan menurunkan daya saing baik nasional maupun internasional. Berdasarkan hasil survey yang dilakukan oleh Transparency International, corruption perception index (CPI) Indonesia tahun 2010 adalah 2,8 dengan posisi 111 dari 180 negara.

Korupsi yang merupakan penyelewengan wewenang atau perbuatan untuk menguntungkan diri sendiri dan golongan. Hal ini timbul karena kurangnya kontrol terhadap kekuasaan yang dimiliki dan terbukanya kesempatan untuk menyelewengkan kekuasaan tersebut disamping ketidakpastian sangsi. Faktor pribadi seperti ingin menjadi kaya, lebih mulia dan terhormat, pola hidup mewah, dan tekanan orang sekitar mendorong terjadinya korupsi (Ackerman, 2004). 
Tidak ada keraguan lagi bahwa korupsi adalah suatu perbuatan jahat yang harus dilawan secara komprehensif oleh penegak hukum, legislatif, eksekutif, dan seluruh lapisan masyarakat. Berbagai upaya dapat dilakukan dalam pemberantasan korupsi meliputi maka upaya memberantas korupsi dilakukan dengan konsep yang mampu mencegah dan menanggulangi korupsi. Konsep tersebut hendaknya meyakinkan bahwa:

1) organisasi pemerintahan mampu mencegah, menangkal serta dapat dengan mudah untuk mendeteksi kejadian korupsi melalui serangkaian upaya kegiatan menurut pendekatan preventif.

2) jika belum dapat atau tidak dapat mencegah, setiap organisasi pemerintahan dapat segera mendeteksi, mengungkapkan fakta kejadian, dan menindaklanjuti sesuai dengan ketentuan yang berlaku melalui serangkaian kegiatan menurut pendekatan InvestigatiffRepresif.

3) setiap organisasi pemerintahan perlu berupaya meningkatkan kepedulian individu di dalam dan di luar organisasi untuk dapat mendorong peran memerangi korupsi sesuai dengan kemampuan yang dimiliki melalui upaya edukatif.

Undang-undang telah mendefinisikan Pemberantasan tindak pidana korupsi sebagai serangkaian tindakan untuk mencegah dan memberantas tindak pidana korupsi melalui upaya koordinasi, supervisi, monitor, penyelidikan, penyidikan, penuntutan, dan pemeriksaan di sidang pengadilan, dengan peran serta masyarakat berdasarkan peraturan perundang-undangan yang berlaku (UU Nomor 30 Tahun 2002). Karenanya ada tiga hal yang perlu digarisbawahi yaitu 'mencegah', 'memberantas' (dalam arti menindak pelaku korupsi), dan 'peran serta masyarakat'.

Penindakan korupsi memang perlu untuk keadilan dan memberikan detterent effect agar para calon pelaku lain berpikir dua kali untuk melakukan hal yang sama. Tetapi tidak semua masalah korupsi selesai dengan penindakan. Di lain pihak kita mengenal corruption by needs dan corruption by greed. Tanpa bermaksud memaklumi korupsi yang dilakukan karena kebutuhan, penindakan yang keras untuk sementara ini bukan merupakan langkah terbaik. Kita harus juga menaruh perhatian pada akar masalahnya, mengapa ini terjadi, untuk kemudian kita perbaiki sistemnya sebagai sebuah langkah pencegahan.

Upaya penindakan (represif) meliputi kegiatan penyelidikan, penyidikan, dan penuntutan. Apabila telah diputuskan dipengadilan dan dinyatakan bersalah, maka penutut umum akan melakukan eksekusi baik terkait dengan eksekusi badan maupun eksekusi uang pengganti dan denda.

Data empiris menunjukkan bahwa $70 \%$ kasus-kasus korupsi yang berhasil diungkapkan selama ini berkaitan dengan penyimpangan dalam pengelolaan anggaran. Hal ini menunjukkan bahwa persoalan besar masih menghadang dalam mewujudkan reformasi keuangan negara. Disamping karena kerakusan dari penyelenggara negara, penyimpangan juga terjadi karena ketidakfahaman aparat pemerintah dalam pengelolaan keuangan negara dan daerah. 


\section{PENCEGAHAN KORUPSI}

Power tends to corrupt, absolute power corrupts absolutely, demikian dikatakan oleh Lord Acton (1887) dalam Gati (2000). Penyalahgunaan kekuasaan bukan hanya terjadi disektor komersial atau kekuasaan birokrasi intansi pemerintah saja namun juga dalam organisasi yang berfokus pada kegiatan sosial. Hal ini telah mendorong banyak pihak untuk melakukan pemisahan fungsi dalam organisasi.

Istilah korupsi termasuk kecurangan (fraud). Young (2000) menyatakan bahwa fraud encompasses an array of irregularities and illegal acts characterized by intentional deception. It can be perpetrated for the benefit of or to the etriment of the organization and by persons outside as well as inside the organization.

Fraud diartikan sebagai berbagai bentuk kecurangan, antara lain penipuan yang disengaja, pengambilan aset kantor, pemalsuan rekening, penyelewengan, dan lai-lain (Lanham et al, 1987)

Menurut Simmons (2004), fraud dapat terjadi apabila penyajian informasi (laporan) dilakukan secara tidak benar dan telah merugikan pihak yang menggunakan informasi tersebut. Fraud dapat menguntungkan individu-individu atau organisasi. Keuntungan individu dapat bersifat langsung (direct) berupa uang dan barang atau tidak langsung (indirect) berupa promosi dan sebagainya. Sedangkan fraud yang menguntungkan organisasi biasanya bersifat langsung (direct) yang berupa financial gain.

Fraud yang dilakukan oleh manajemen untuk keuntungan kelompoknya dan perusahaan telah banyak merugikan pihak prinsipal. Penyelewengan dilakukan secara sistematis maupun secara nyata seperti pembobolan bank. Fraud yang demikian akhir-akhir ini menjadi semakin marak dengan dimotori oleh para elit perusahaan. Banyak kasus besar seperti Enron dan Bank Bali telah menyita perhatian publik. Fraudulent activity pada awalnya dilakukan oleh siapa saja dalam setiap level organisasi. Namun pada akhir-akhir ini yang menjadi pembuat kekacauan terbesar adalah para pemimpin organisasi melalui manipulasi informasi keuangan ( financial fraud) (Moeler, 2004)

Menurut Treadway, jr (1987) : fraudulent financial reporting as intentional or reckless conduct, whether act or omission, that results in materially missleading financial statements. Fraudulent financial reporting merupakan tindakan kesengajaan untuk menyajikan kesalahan atau menghilangkan suatu jumlah tertentu dalam laporan keuangan sehingga akan menurunkan kredibilitas laporan keuangan bagi para pengguna laporan keuangan tersebut.

Fraudulent financial reporting terjadi dengan (a) manipulasi, pemalsuan catatan akuntansi atau dokumen pendukung laporan keuangan, sengaja menghilangkan kejadian, transaksi, dan informasi penting dari laporan keuangan, dan sengaja menerapkan prinsip akuntansi yang salah, dan (b) misappropriation of assets meliputi; penggelapan penerimaan kas, pencurian aktiva, dan hal-hal yang menyebabkan organisasi membayar barang atau jasa yang tidak diterimanya.

Penyalahgunaan akuntansi untuk memperlancar penyelewengan banyak ditunjukkan dalam beberapa kasus besar seperti halnya dengan Enron. Perlakuan 
akuntansi yang demikian disebut dengan creative accounting. Dengan creative accounting, organisasi dapat menggunakan keahliannya dalam melakukan pemilihan teknik dan metode akuntansi, legal maupun illegal sehingga dapat melakukan manipulasi informasi akuntansi (Mulford and Comiskey ,2002).

Menurut Amat et al. [1999] creative accounting merupakan sebuah proses dimana beberapa pihak menggunakan kemampuan pemahaman pengetahuan akuntansi dan menggunakannya untuk memanipulasi pelaporan keuangan. Sebagai accounting manipulation, creative accounting dapat dilakukan melaui penerapan 'earning management', 'income smoothing' dan 'creative accounting itu sendiri (Stolowy dan Breton, 2000).

Menurut Naser [1993] dalam Amat et.al. [1999] creative accounting adalah :

The process of manipulating accounting figures by taking advantage of loopholes in accounting rules and the choice of measurement and disclosure practices in them to transform financial statements from what they should be, to what prepares would prefer to see reported, ......and the process by which transactions are structured so as to produce the required accounting results rather than reporting transaction in neutral and consistent way.

Kesalahan penyajian laporan keuangan terjadi karena adanya fraudulent financial reporting dan misappropriation of assets (National Commission on Fraudulent Financial Reporting, 1987). Fraudulent financial reporting terjadi karena salah penyajian yang tidak disengaja atau disengaja dengan memanipulasi, menghilangkan, atau menambah informasi tertentu dalam laporan keuangan.

Sebagai fihak yang paling kompeten dan kapabel dalam masalah finansial, akuntan berkewajiban untuk mencegah terjadinya fraudulent financial reporting sebagaimana dijelaskan sebelumnya. Inilah salah satu kontribusi akuntan dalam upaya pemberantasan dan pencegahan korupsi di Indonesia. Dengan pencegahan terhadap fraud dalam laporan keuangan, maka akuntan ikut aktif dalam membangun good governance dan pencegahan korupsi.

Salah satu unsur penting dalam upaya menjadikan Indonesia yang bersih dan bebas dari korupsi adalah melalui upaya pencegahan korupsi. Mengingat korupsi terjadi karena adanya dua unsur yakni niat dan kesempatan, maka upaya pencegahan yang dapat dilakukan adalah dengan membangun sistem yang efektif untuk menekan kesempatan orang melakukan korupsi. Salah satu sistem yang efektif adalah dengan penerapan good governance di pemerintahan dengan tiga unsur pentingnya yakni transparansi, partisipasi, dan akuntabilitas.

Selama kurun waktu sepuluh tahun terakhir wacana tentang pentingnya implementasi good governance telah banyak didiskusikan dalam seminar dan berbagai pertemuan ilmiah maupun praktisi. Namun demikian, perwujudannya masih sebatas formalitas dan belum menunjukkan perubahan berarti dalam hubungan antara penguasa, dunia bisnis, dan masyarakat. Fakta menunjukkan walaupun good governance telah diterapkan masih banyak terjadi korupsi terutama yang berkaitan dengan pengedaan barang dan jasa pemerintah. Berbagai jenis delik korupsi seakan bermunculan dalam pelaksanaan kekuasaan oleh 
berbagai otoritas kekuasaan di Indonesia. Suatu peristiwa dapat dikategorikan sebagai peristiwa pidana korupsi apabila memenuhi unsur: (a) ada pelaku yang menyebabkan terjadinya korupsi yakni orang perseorangan yang termasuk subyek hukum tindak pidana korupsi (TPK) adalah pegawai negeri dan atau swasta. (b) perbuatan tersebut telah menguntungkan atau memperkaya dirinya sendiri, orang lain ataupun korporasi. (c) perbuatan tersebut telah melanggar hukum baik formil maupun materil atau menyalahgunakan kewenangannya, dan (d) perbuatan tersebut dapat mengakibatkan krugian keuangan negara atau perekonomian negara.

Dalam rangka mewujudkan good governance yang efektif mendukung pencegahan korupsi diperlukan partisipasi dari berbagai pihak. Mengingat korupsi adalah kejahatan yang luar biasa (extra ordinary crime), maka harus dibrantas dengan cara-cara yang juga luar biasa. Pemberantasan korupsi dan pencegahan korupsi bukan hanya menjadi tanggungjawab para penegak hukum namun juga perlu adanya partispasi dari seluruh lapisan masyarakat. Salah satu korupsi yang menyebabkan rendahnya indeks persepsi korupsi Indonesia sehingga sampai dengan saat ini Indonesia tetap dianggap sebagai negara korup adalah banyaknya korupsi pada sektor pelayanan publik. Oleh kerena itu. para pemegang otoritas kekuasaan pada setiap level pemerintahan dan instansi pelayanan publik harus memperkuat instansinya untuk tetap berorientasi pada masrakat. (Langseth, 1999; Langseth,et al 1997).

Dari sudut pandang fungsional, governance tercerminkan dari sejauhmana fungsi pemerintah telah berjalan secara efektif dalam upaya mencapai tujuan yang telah ditetapkan, atau sebaliknya. Secara umum, governance diartikan sebagai kualitas hubungan antara pemerintah dan masyarakat yang dilayani dan dilindunginya. Governance mencakup 3 (tiga) domain yaitu state (negara/pemerintahan), private sectors (sektor swasta/dunia usaha), dan society (masyarakat).

Menurut UNDP (1997) mendefinisikan governance sebagai "the exercise of political, economic, and administrative authority to manage a nation's affair at all levels". Oleh karena itu, governance dapat ditinjau dari tiga sudut pandang yaitu ekonomi, politik, dan administrasi. Economic governance meliputi proses-proses pembuatan keputusan yang memfasilitasi aktivitas ekonomi di dalam negeri dan interaksi diantara penyelenggara ekonomi. Economic governance mempunyai implikasi terhadap equity, poverty, dan quality of life. Political governance adalah proses-proses pembuatan keputusan untuk formulasi kebijakan. Administrative governance adalah sistem implementasi proses kebijakan.

Dalam governance, institusi pemerintahan berfungsi menciptakan lingkungan politik dan hukum yang kondusif, sektor swasta menciptakan pekerjaan dan pendapatan, sedangkan society berperan positif dalam interaksi sosial, ekonomi, dan politik, termasuk mengajak kelompok-kelompok dalam masyarakat untuk berpartisipasi dalam aktivitas ekonomi, sosial dan politik. Negara (state), sebagai suatu unsur governance, didalamnya termasuk lembaga-lembaga politik dan lembaga-lembaga sektor publik. Sektor swasta meliputi organisasi-organisasi swasta yang bergerak diberbagai bidang sektor informal lain di pasar. Sektor 
swasta berbeda dengan masyarakat karena sektor swasta mempunyai pengaruh terhadap kebijakan-kebijakan sosial, politik dan ekonomi yang dapat menciptakan lingkungan yang lebih kondusif bagi pasar dan organisasi-organisasi itu sendiri. Sedangkan masyarakat (society) terdiri dari individu-individu maupun kelompokkelompok (baik yang terorganisir maupun tidak) yang berinteraksi secara sosial, politik dan ekonomi dengan aturan-aturan formal maupun tidak formal. Masyarakat meliputi lembaga swadaya masyarakat, organisasi profesi dan lain-lain.

Selanjutnya dalam good governance arti good mengandung dua pengertian. Pertama, nilai-nilai yang menjunjung tinggi keinginan/kehendak rakyat, dan nilainilai yang dapat meningkatkan kemampuan rakyat dalam pencapaian tujuan (nasional) kemandirian, pembangunan berkelanjutan dan keadilan sosial. Kedua, aspek-aspek fungsional dari pemerintahan yang efektif dan efisien dalam pelaksanaan tugasnya untuk mencapai tujuan-tujuan tersebut.

World Bank (2002) mengungkapkan pemahaman good governance sejajar dengan penyelenggaraan manajemen pembangunan yang solid dan bertanggungjawab dengan menerapkan demokrasi (kedaulatan rakyat) seiring dengan kedaulatan hukum dan mekanisme pasar yang efisien, penghindaran salah alokasi dana investasi yang langka, dan pencegahan korupsi baik secara politik maupun administratif, menjalankan disiplin anggaran serta penciptaan iklim yang kondusif bagi tumbuh dan berkembangnya dunia usaha. Sementara itu UNDP (1997) memandang good governance sebagai hubungan sinergis dan konstruktif antara negara, sektor swasta dan masyarakat. Dalam konteks tersebut UNDP mengetengahkan beberapa karateristik dari good governance, sebagai berikut :

a. Participation. Setiap warga negara mempunyai suara dalam pembuatan keputusan, baik secara langsung maupun melalui intermediasi institusi legitimasi yang mewakili kepentingannya. Partisipasi seperti ini dibangun atas dasar kebebasan berasosiasi dan berbicara serta berpartisipasi secara konstruktif.

b. Rule of Law. Kerangka hukum harus adil dan dilaksanakan tanpa pandang bulu, terutama hukum untuk hak asasi manusia.

c. Transparency. Transparansi dibangun atas dasar kebebasan arus infornasi. Proses-proses, lembaga-lembaga dan informasi secara langsung dapat diterima oleh mereka yang membutuhkan. Informasi harus dapat dipahami dan dapat dimonitor.

d. Responsiveness. Lembaga-lembaga dan proses-proses harus mencoba untuk melayani setiap stakeholders.

e. Consensus Orientation. Good governance menjadi perantara kepentingan yang berbeda untuk memperoleh pilihan terbaik bagi kepentingan yang lebih luas baik dalam hal kebijakan-kebijakan maupun prosedur-prosedur.

f. Equity. Semua warga negara, baik laki-laki maupun perempuan, mempunyai kesempatan untuk meningkatkan atau menjaga kesejahteraan mereka.

g. Efectiveness and efficiency. Proses-proses dan lembaga-lembaga menghasilkan sesuai dengan apa yang telah digariskan dengan menggunakan sumber-sumber yang tersedia sebaik mungkin. 
h. Accountability. Para pembuat keputusan dalam pemerintahan, sektor swasta dan masyarakat (civil society) bertanggungjawab kepada publik dan lembagalembaga stakeholders. Akuntabilitas ini tergantung pada organisasi dan sifat keputusan yang dibuat, apakah keputusan tersebut untuk kepentingan internal atau eksternal organisasi.

i. Strategic Vision. Para pemimpin dan publik harus mempunyai perspektif good governance dan pengembangan manusia yang memiliki visi luas dan jauh kedepan sejalan dengan apa yang diperlukan untuk pembangunan.

Seperti kita ketahui bersama, tidak akan ada pemerintahan yang bersih dan bebas dari korupsi, tanpa penataan sistem manajemen pemerintahan sesuai dengan prinsip-prinsip pemerintahan yang baik. Hasil penelitian World Bank dan lembaga internasional lainnya menegaskan, bahwa kebijakan-kebijakan yang tepat, investasi yang baik maupun usaha-usaha untuk memerangi korupsi tidak akan mampu tumbuh secara baik dan berkesinambungan dalam lingkungan pemerintahan yang memiliki institusi publik yang tidak berfungsi dan praktik kepemerintahan yang buruk.

Penerapan good governance pada akhirnya akan terwujud dengan pertanda adanya peningkatan pelayanan kepada masyarakat dan terselenggaranya pemerintahan yang transparan, partisipatif, dan akuntabel. Dalam beberapa tahun belakangan mulai bermunculan implementasi one stop service pada beberapa pemerintah daerah untuk peningkatan pelayanan publik khususnya yang terkait dengan layanan perijinan. Kemudahan pemberian layanan publik ini diharapkan akan mengurangi keengganan berinvestasi. Investasi diharapkan akan masuk karena pemerintahan yang melayani dengan baik dipersepsikan sebagai pemerintahan yang bersih, baik karena kemudahan yang diberikan, maupun karena tidak adanya biaya-biaya siluman yang memberatkan.

Berbagai penelitian nasional dan internasional mengaitkan secara langsung maupun tidak langsung antara korupsi (yang diwakili oleh ketepatan mutuprosedur/waktu-biaya layanan publik) dengan tingkat investasi, tingkat kemiskinan, dan bahkan dengan berbagai tolok ukur pembangunan seperti angka kematian bayi, tingkat pendapatan perkapita dan angka melek huruf (Mauro, 1995; Campos and Pradan; Shang; Kaufman et al, 1999). Karena itu tidak mengherankan jika dalam pengantar hasil surveinya Transparency International menyatakan bahwa pada negara-negara miskin dengan level korupsi yang parah, korupsi bisa berarti perbedaan antara hidup dan mati (Transparency International, 2008).

\section{HARAPAN TERHADAP AKUNTAN}

The Economic Development Institue (EDI) of the World Bank dalam Ulum (2004) menyatakan bahwa dalam rangka upaya memberantas KKN, terutama korupsi, telah memperkenalkan konsep yang disebut "Pillars of integrity".(Langseth, Stapenhurst, and Pope, 1997; Dye and Stapenhurst, 1998). Pillars of integrity yang diperkenalkan meliputi delapan unsur penting dalam good governance mencakup eksekutif, parlemen, kehakiman, pengawas (meliputi auditor pemerintah meliputi BPK, BPKP, dan Inspektorat Jenderal, Inspektorat, Bawasda, Satuan Pengawas Intern, dan Kantor Akuntan Publik), media, sektor 
swasta (KADIN, Komite Pengusaha Anti Suap, Asosiasi Industri dan Profesional), masyarakat sipil, dan lembaga penegak hukum (meliputi kepolisian, kejaksaan, dan Komisi Pemberantasan Korupsi (KPK)).

Sebagai salah satu unsur penting dalam kegiatan perekonomian di Indonesia, akuntan juga menjadi bagian dalam pillars of integrity. Peran akuntan sebagai auditor yang bernaung pada lembaga pengawasan seperti Badan Pemeriksa Keuangan (BPK), Badan Pengawasan keuangan dan Pembangunan (BPKP), Inspektorat Jenderal dan Inspektorat, Badan Pengawas Daerah, SPI, dan Kantor Akuntan Publik sangat dibutuhkan dalam mewujudkan akuntabilitas publik. Disamping itu peran akuntan dalam manajemen sangat penting untuk penyajian informasi keuangan yang kredibel sehingga menumbuhkan kepercayaan pada masyarakat.

Seperti didiketahui lembaga-lembaga pengawa banyak diisi oleh para auditor yang profesional. Banyak informasi mengenai dagaan tindak pidana korupsi dihasilkan dari pemeriksaan yang dilakukan oleh auditor. Dengan demikian jelas ada atau tidaknya penyelewengan keuangan sangat tergantung dari pekerjaan dan kesimpulan yang direkomendasikan oleh para akuntan yang berprofesi sebagai auditor.

Dengan ekspektasi yang besar dari masyarakat akan integritas dan profesionalisme para akuntan, maka akuntan harus terus menerus meningkatkan kapabilitas dan kompetensinya dibidang tugas masing-masing. Para akuntan dituntut untuk tetap menjunjung tinggi etika dan independensi mereka. Kriteria auditor yang berkerja secara profesional antara lain : meningkatkan dan mengembangkan ilmu dan seni akuntansi, menjaga kepercayaan publik kepada profesi, mengadakan dan menjalankan setiap program dan kegiatan profesi yang bertujuan untuk mengingkatkan kualitas jasa yang diberikan profesi.

Kewajiban lain yang harus dipikul akuntan agar dapat berperan sebagai salah satu "pillars of integrity" adalah menajdi salah satu agen yang ikut membangun terwujudnya good governance. (Shunglu, 1998). Peran ini diimplementasikan melalui penciptaan keterbukaan dan akuntabilitas dalam penyajian laporan keuangan organisasi baik pemerintah maupun swasta. Disamping itu kontribusi akuntan dapat diberikan kepada penegak hukum untuk membawa kasus-kasus korupsi ke pengadilan.

Banyak lembaga-lembaga yang penting dalam membangun kehidupan bangsa dan negara seperti LSM, lembaga ombudsman dan lembaga kemasyarakatan lainnya, terbatas pemahaman dan pengetahuan mereka mengenai laporan keuangan dan pemeriksaan keuangan yang paling sederhana sekalipun. Akuntan dapat membantu mereka dengan memberikan pengetahuan praktis atau jika memungkinkan memberikan bantuan sumberdaya manusia. Selanjutnya jika dimungkinkan akuntan dapat bekerja sama menyiapkan petunjuk praktis pengetahuan laporan keuangan dan pemeriksaan keuangan bagi organisasi masyarakat di tingkat paling bawah seperti RT dan RW.

Akuntan juga diharapkan mampu membantu usaha kecil dalam pelaporan dan pemeriksaan laporan keuangan. Dengan pemahaman masyarakat akan pemeriksaan keuangan pada tingkat yang paling sederhana semakin meningkat, 
selanjutnya masyarakat akan terbiasa dengan prinsip keterbukaan dan akuntabilitas. Kondisi tersebut sangat mendukung iklim good governance. Peran lain yang didapat adalah untuk mendukung gerakan anti-korupsi yang merupakan salah satu elemen gerakan untuk menciptakan good governance dengan memberikan dukungan teknis kepada gerakan atau lembaga anti-korupsi. Dukungan teknis sangat mungkin dilakukan karena akuntan dapat mengetahui secara teknis ada tidaknya penyelewengan keuangan atau korupsi dengan bertindak sebagai auditor.

Agar tetap dapat berkomitmen dan memainkan peran aktif sebagai salah satu unsur pillar of integrity, akuntan harus: mampu meningkatkan profesionalisme anggotanya, mampu membina, mengawasi, dan menindak anggotanya yang melanggar etika profesi, mampu meyakinkan kepada masyarakat bahwa akuntan publik tidak terlibat dalam proses terjadinya korupsi dan juga kolusi, berperan aktif mempromosikan gerakan anti korupsi, dan memberi dukungan dan bantuan kepada lembaga atau gerakan anti korupsi. Dengan mampu menjalani ke 5 peran tersebut di atas maka akuntan publik telah mampu menjalankan peran sentral dalam gerakan anti-korupsi, dimana gerakan tersebut merupakan salah satu upaya untuk menuju terciptanya good governance.

Dengan demikian lingkup aktivitas profesi akuntan semakin luas, tentunya memilki implikasi yang luas pula salah satunya adalah tantangan bagaimana akuntan mampu mengembangkan kualitas profesinya. Sebab untuk dapat melaksanakan aktivitas-aktivitas di atas, maka keahlian yang perlu disiapkan oleh para akuntan juga menjadi semakin kompleks. Meski begitu, peningkatan lingkup aktivitas tersebut, juga merupakan peluang bagi profesi akuntan untuk memperluas jasa-jasa yang ditawarkan.

Dalam konteks ini, untuk mengimbangi luasnya lingkup aktivitas profesi akuntan, maka keahlian-keahlian atau pengetahuan berikut perlu dimilki para akuntan. Pertama, pengetahuan tentang hukum bisnis. Tujuannya adalah, agar para akuntan mampu mengidentifikasi perilaku-perilaku bisnis (seperti monopoli, kartel, oligopoli, dsb). Kedua, pemahaman tentang ekonomi industri. Pemahaman ini diperlukan agar para akuntan mampu mengidentifikasi struktur industri serta posisi perusahaan dalam industri.

Ketiga, keahlian sebagai analis. Kenyataan di Amerika Serikat menunjukkan bahwa peran analis ternyata jauh di atas dibandingkan peran laporan hasil audit (yaitu 70\%, sedangkan laporan hasil audit 30\%). Mengapa demikian? Setidaknya ada dua faktor yang menyebabkan perbedaan tersebut: (1) para analis mampu membuat laporan keuangan menjadi lebih hidup melalui analisa-analisa kuantitatif (seperti analisis rasio dan prediksi kebangkrutan melalui data-data keuangan), (2) selain analisis kuantitatif para analis juga memberikan analisis kualitatif, seperti budaya perusahaan, keunggulan manajemen, prospek pertumbuhan dan strategi pencapaiannya yang kesemuanya tidak terekam dalam laporan keuangan.

Secara institusi, dengan adanya tuntutan yang begitu besar terhadap peran akuntan dalam mewujudkan good governance, lembaga profesi akuntan (IAI) perlu menata kembali aktivitas yang dilakukan para anggotanya. Selain membekali berbagai keahlian seperti tersebut di atas, melalui berbagai program Pendidikan 
Profesi Berkelanjutan. , secara legalitas IAI juga perlu memperkuat landasan bagi profesi akuntan. Dalam konteks ini, jika selama ini standar akuntansi dan auditing yang telah ditetapkan masih mengacu pada catatan keuangan (kuantitatif) semata, maka kini saatnya informasi kualitatif disertakan dalam standar.

Dengan demikian, bagi IAI kini sudah saatnya untuk mempertimbangkan membuat suatu standar agar informasi kualitatif menjadi bagian dalam pelaporan keuangan yang disampaikan kepada publik. Sementara itu, pertimbangan penentuan opini terhadap sebuah laporan keuangan patut juga mempertimbangkan dan mendasarkan pada pada kewajaran laporan keuangan dan pertimbangan informasi kualitatif yang terjadi pada perusahaan, seperti kewajaran transaksi.

Zeune (1994:150) menyatakan bahwa salah satu peran penting akuntansi dalam upaya preventif terhadap korupsi adalah melalui kredibilitas pengungkapan informasi akuntansi. Permasalahan dalam pelaporan akan mengurangi upaya preventif dalam mencegah berlangsungnya praktek korupsi. Hal ini sesuai dengan pengungkapan dari global corruption report 2001 yang menyatakan bahwa organisasi yang korup akan berupaya untuk tidak transparan kepada publik.

Klitgard (1988), menyatakan bahwa salah satu komponen dalam strategi pembersihan korupsi adalah dengan menciptakan system evaluasi kinerja yang dilakukan oleh kegiatan audit. Kekuasaan yang dijalankan secara akuntabel akan mencegah terjadinya korupsi.

Dalam Introducing the Global Corruption Report 2001 (Eigen) dan Kemitraan Bagi Pembaruan Tata Pemerintahan di Indonesia (2002), mengungkapkan bahwa keterbukaan (transparency) merupakan instrumen yang efektif untuk pencegahan terhadap korupsi. Keterbukaan yang diawali dari kesiapan organisasi untuk melaksanakan suatu amanah, merencanakan, melaksanakan berbagai program dan kegiatan, sampai pelaporan sangat efektif untuk terwujudnya organisasi yang bebas korupsi dan akuntabel (Marshall, 2001).

Jika ini dapat diwujudkan, pandangan skeptis terhadap peranan profesi akuntan dalam mewujudkan good governance dapat ditekan. Di sisi lain, dengan makin luasnya lingkup aktivitas, profesi akuntan akan makin diminati konsumen karena lengkapnya jasa-jasa yang dapat disediakan. Bila dahulu seorang investor yang hendak menanamkan modal memerlukan dua profesi keahlian (akuntan dan analis), maka kini investor tinggal "bertransaksi" dengan satu profesi.: akuntan. Dengan demikian, peran akuntan tidak lagi minimal (seperti yang ditunjukkan dengan pemanfaatan laporan hasil audit yang hanya $30 \%$ ), tetapi kelak dapat maksimal.

Accounting choice merupakan salah satu cara dalam creative accounting practices (Mulford dan Comiskey, 2002). Praktik-praktik ini memberikan peluang bagi organisasi untuk melakukan berbagai penyelewengan dan korupsi. Dalam kasus Enron, perusahaan menerapkan creative accounting untuk hal-hal seperti off balance sheet, timing of revenue recognition and estimation of value of merchant investment. Dengan pemilihan metode akuntansi, perusahaan secara 'kreatif dapat merancang tampilan kinerja' yang diinginkan manajemen sebagaimana yang terjadi dalam income smoothing (Moses, 1997). 
Peranan financial information adalah memberikan informasi bagi penggunanya dalam proses pengembilan keputusan-keputusan strategisnya. Financial information bermanfaat untuk yakni (a) untuk memfasilitasi para pengambil keputusan (investor) untuk menetapkan alternatif yang akan dipilih, (b) menghubungkan berbagai stakeholders seperti manajemen dan investor; dan (c) peningkatan akuntabilitas publik.

Skandal finansial menjadi bagian dari pemberantasan praktik korupsi, kolusi, dan nepotisme serta persoalan rumit yang terkait dengan penegakan hukum dan upaya untuk mengembalikan kepercayaan investor bagi kepentingan pemulihan ekonomi. Rendahnya kepercayaan terhadap kebenaran informasi yang tersaji dalam laporan keuangan emiten, atau keabsahan dari jenis informasi yang disampaikan dalam rangka keterbukaan, paralel dengan persoalan di seputar nasib investor yang menjadi korban dari praktik kotor yang mencuat selama ini.

Transparansi dan akuntabilitas akan menjadi utopia apabila para akuntan tidak berkerja sesuai dengan harapan masyarakat dalam menyajikan Informasi akuntansi dan keuangan yang merupakan salah satu public goods. Oleh karena itulah, para akuntan memainkan peran penting untuk membangun manajemen Informasi keuangan yang kredibel. Dengan pengetahuan yang dimiliki dan dukungan profesi serta harapan besar dar masyarakat menjadi bekal yang tidak kecil untuk ikut berperan dalam upaya pemberantasan korupsi di Indonesia.

Para praktisi akhir-akhir ini dituding kurang berpihak kepada kepetingan publik. Kasus Enron, Wordcom, dan Merck di AS baru-baru ini telah membuat panik para investor di Amerika bahkan global investor. Hal itu mungkin bukanlah merupakan peristiwa yang sangat menarik untuk dibicarakan. Mungkin hal itu bukan pula sebagai tragedy yang harus berlarut-larut disesali, kalau saja itu semata-mata disebabkan business failures.

Sebagai pihak yang menyajikan infprmasi kepada publik dimana informasi tersebut bermanfaat untuk pengambilan keputusan-leputusan strategis dan ekonomis, maka akuntan perlu menjalankan peran dan fungsinya sesuai dengan harapan tersebut. Konsep-konsep atau model-model pengaturan perlu disesuaikan dan dirubah berdasarkan semangat pelayanan kepada kepentingan publik? Akankah pemulihan public confidence akan mendasari perubahan-perubahan itu? Pertanyaan-pertanyan inilah yang harus respon akuntan, karena sangat menentukan dalam mereposisi dirinya di masyarakat. Untuk menjawab pertanyaan-pertanyaan tersebut hal yang paling penting untuk direnungkan adalah bahwa profesi ini ada karena ada kepentingan publik yang harus dilayani. Kepentingan publik tercermin dalam laporan keuangan dan laporan hasil audit atas laporan keuangan yang disajikan oleh akuntan.

\section{SIMPULAN}

Klitgard (1988), menyatakan bahwa salah satu komponen strategi pembersihan korupsi adalah dengan kegiatan audit. Eigen (2001) dan Kemitraan Bagi Pembaruan Tata Pemerintahan di Indonesia (2002), mengungkapkan bahwa transparency merupakan instrumen efektif untuk pencegahan korupsi. Diawali dari kesiapan organisasi untuk melaksanakan amanah, merencanakan, melaksanakan 
berbagai program dan kegiatan, sampai pelaporan sangat efektif untuk terwujudnya organisasi yang bebas korupsi dan akuntabel (Marshall, 2001).

$$
\text { Power }- \text { Accountability = Corruption }
$$

Dengan terjadinya korupsi akan mendorong pemborosan keuangan atau kekayaan negara dan juga swasta. Korupsi dapat mengurangi kredibilitas organisasi dan menghambat pertumbuhan atau perkembangan usaha yang sehat dan akuntabel (Elliot, 1999; Reinikka dan Svenson, 2003; Saleh dan Iqbal,1995).

Korupsi telah mengakibatkan kemiskinan, kebodohan, keterpurukan, dan keterbelakangan bagi anak-anak bangsa. Akibat yang ditimbulkannya itu menggambarkan sifatnya sebagai kejahatan yang luar biasa, karena kita harus punya semangat luar biasa untuk memberantasnya. Upaya represif dan preventif harus dilakukan untuk efektivitas pemberantasan korupsi, dan harus melibatkan seluruh masyarakat.

Sebagai penyedia barang publik (public goods) yang berupa informasi akuntansi, para akuntan sangat diharapkan kemapuan dan integritasnya dalam menjalankan profesi yang sangat diharapkan masyarakat banyak. Informasi yang disediakan oleh para akuntan baik informasi akuntansi dalam laporan keuangan perusahaan maupun informasi hasil audit akan berpengaruh dalam setiap pengambilan keputusan ekonomi yang terkait dengan hal tersebut. Oleh karena itu akuntan dituntut peran sertanya dalam upaya pemberantasan korupsi seperti yang sudah dan sedang dilakukan oleh masyarakat banyak di Indonesia.

Akuntan dapat berperan dalam upaya penindakan korupsi melalui pemberian bantuan audit investigasi, audit forensik, penghitungan kerugian negara dan pengumpulan bahan keterangan yang akan dijadikan barang bukti dan alat bukti oleh penegak hukum. Akuntan juga dapat memberikan kontribusi besar dalam memberikan keterangan ahli baik kepada penyidik maupun majelis hakim di persidangan perkara tindak pidana korupsi.

Dalam upaya pencegahan korupsi, akuntan berperan besar dalam penyediaan informasi akuntansi yang kredibel. Akuntan berkewajiban untuk mencegah terjadinya fraudulent financial reporting yang banyak terjadi dalam skandal-skandal besar keuangan di dunia dan di Indonesia. Disamping itu para akuntan juga diharapkan dapat membantu pemerintah dalam menyiapkan tenaga pengelola keuangan negara yang handal dan berintegritas. Akuntan juga berperan dalam perhitungan dampak yang ditimbulkan oleh suatu tindak pidana korupsi. Kuantifikasi dampak korupsi akan menjadi dasar bagi penegak hukum dan masyarakat untuk menetukan tindakan yang perlu diambil untuk upaya pemberantasan dan pencegahan korupsi. Inilah kontribusi nyata para akuntan dalam membangun sistem pencegahan korupsi dalam kerangka pembangunan good governance. 


\section{DAFTAR PUSTAKA}

Ackerman, Susan Rose. 2004, Corruption, Susan Rose-Ackerman@Yale.edu, Yale University.

Alatas, Syed Hussein. 1987. Korupsi, Sifat, Sebab dan Fungsi, Jakarta, LP3ES.

Amat, Oriol., Blake, John., and Dowds, Jake. 1999. The Ethics of Creative Accounting, Ecconomic Working Paper, Journal of Ecconomic Literature Classification:M41, December 1999.

Barata, Kimberly., Cain, Piers., Thurston, Anne. 1999. From Accounting to ccountability, Managing Accounting Records as a Strategic Resource, International Records Management Trust, World Bank infoDEV Programme.

Belkaoui, Ahmed. 1993. Accounting Theory, Hoarcourt Brace, Jovanovich, New York.

Ben Olken /Abhijit Banerjee. 2007. Harvard Univ, MIT, \& J- Poverty, 2007, The sosial cost of corruption.

Campos, Edgardo and Pradhan, Sanjay. 1999. The impact of corruption on investment: predictability matters.

Carlin, Tyrone M. 2001. Performance and Transparency, Are Australia's Leading Edge System Really Working?

Center for the Study of Democracy. 1998. Accounting for Corruption: economic structure, Democratic Norms, and Trade, University of California Irvine, USA.

Dye, Kenneth M. and Stapenhurst, R., 1998, Pillars of Integrity: the Importance of Supreme Audit Instituions in Curbing Corruption, EDI Working Paper, The Economic Development Institute of the World Bank, 1998.

Eliot, Kimberly Ann., 1997. Corruption and the Global Economy, Washington, DC, Institue for Internation Economics.

Eigen. 2001. Global Corruption Report, echoes a clarion call for a worldwide coalition that willtolerate no safe haven for corruption and money laundering, Transparency International, Washington DC.

Floridi, Luciano., 2004. Open Problems in the Philosphy of Information, Metaphilosophy LLC and Blackwell Publishing Ltd, Vol. 35, No. 4, July 2004. 
Gati, Charles. 2000. Kohl \& Co, www.interinvest.com/PDF/feb00.PDF.

Kaufmann, Daniel, Aart Kraay, and Pablo Zoido-Lobaton. 1999. Governance Matters, World Bank Policy Research Working Paper No. 2196.

Langseth, Petter. 1999. Prevention, An Effective Tool to Reduce Corruption, Vienna

Langseth, Petter, Stapenhurst, R., Pope, J. 1997. The Role of National Integrity System in Fighting Corruption, EDI Working Paper, The Economic Development Institute of the World Bank.

Klitgaard, Robert, 1988. Controlling Corruption, Oxford, England, University of California Press.

Kemitraan Bagi Pembaruan Tata Pemerintahan di Indonesia, Pebruari 2002. Survey Nasional Mengenai Korupsi di Indonesia-Laporan Akhir.

Lanham, D. Weinberg, M. Brown, K.E. \& Ryan, G.W. 1987. Criminal Fraud, Law Book Company, Sidney

Marshal, Ian E. 2001, Survey of Corruption Issues in The Mining and Mineral Sector, Mining, Mineral and Sustainable Development Project, London.

Moses G.D. 1987. Income Smoothing and Incentives, Empirical Test Using Accounting Changes, Accounting Review, April: 358-377.

Moeler, Robert and Herbert N. Witt, 1999. Internal Auditing, $5^{\text {th }}$ ed. New York, John Willey \& Son, Inc.

Moeler, Robert N. 2004. Sarbanes Oxley and the New Internal Auditing Rules, Canada, John Wiley and Son.

Mauro, Paolo (1995), Corruption and Growth, The Quarterly Journal of Economics, August 1995.

Mulford, Charles W. dan Eugene E. Comiskey. 2002. The Financial Numbers Game, New York, NY ,John Willey and Son inc.

Pavarala, Vinod. 1996. Interpreting Corruption Elite Perspsctives in India, London, Sage Publication.

Pope, J. 2000. TI Source Book 2000 Confronting Corruption, The Elements of a National Integrity System. Germany: Transparency International. 
Reinikka, Ritva dan Jacob Svenson. 2003. Survey Techniques to Measure and Explain Corruption, World Bank Policy Research, Washington DC.

Romney, Marshall B.. and Paul John Steinbart. 2003. Accounting Information System, 9th ed,PrenticeHall Sanfrancisco, California , Joset-Bas Inc, Publisher.

Saleh, Sirajuddin H., Aslam Iqbal. 1995., Accountability, The Endless Prophecy. The Asian and Oacific Development Center.

Simmons, Mark R. 2004. Recognizing the Elements of Fraud, Certified Fraud Examiner, http://www.facilitatedcontrols.com/fraud-investigation/ fraudwww. $\underline{\mathrm{htm}}$.

Tanzi, Vito. 1998. Corruption Around the World. IMF Staff Papers. Washington, D.C. International Monetary Fund.

Treadway, James C. Jr et al, 1987. Report of The national Commission on fraudulent Financial Reporting, National Commission on Fraudulent Financial Reporting

Transparency International. 2008. Transparency International 2008 Corruption Perceptions Index - Immediate Release.

Undang-Undang Republik Indonesia Nomor 31 Tahun 1999 sebagaimana diubah dengan Undang-Undang Nomor 20 Tahun 2001 tentang Pemberantasan Tindak Pidana Korupsi.

UNDP. 1997. UNDP Policy Paper, Governance for Sutainable Human Development, A policy Document.

UNDP Indonesia. Indonesia Millennium Development Goals Report 2004, United Nations Development Programme Indonesia: Jakarta, 2003

Ulum, Ihya. 2004. Peran IAI Dalam Mewujudkan Good Governance: Sebuah Kajian Atas Tuntutan Profesionalisme Akuntan Dalam Pelaksanaan Audit Keuangan Partai Politi, di Jurnal Akuntansi dan Keuangan "BALANCE", Volume 1/No. 2/April-September 2004. ISSN: 1693-3796

Undang-Undang Republik Indonesia Nomor 30 Tahun 2002 tentang Komisi Pemberantasan Tindak Pidana Korupsi.

Wei, Shang-Jin. Smarzynska, Beata. 2000. Corruption and the Composition of Foreign Direct Investment: firm-level evidence, World Bank Working Paper No. 2360. 
World Bank. 1992. Governance and Development, The World Bank, Washington DC, USA.

Young, Michael R. 2000. Accounting Irregularities and Financial Fraud, A Corporate Governance Guide

Zeune, Gary D. 1994. The CEO's Complete Guide to Committing Fraude, Columbus, Ohio, Lori Pingel and Association. 